

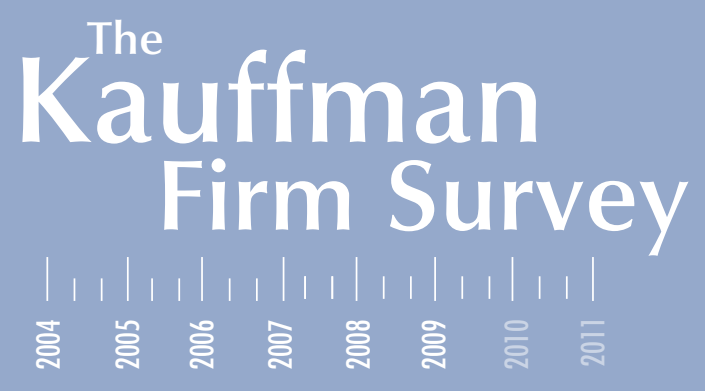

\title{
Casting a Wide Net: Online Activities of Small and New Businesses in the United States
}

\author{
Alicia M. Robb \\ Senior Research Fellow \\ Ewing Marion Kauffman Foundation \\ E.J. Reedy \\ Research Fellow \\ Ewing Marion Kauffman Foundation
}

October 2011

\section{KAUFFMAN}

The Foundation of Entrepreneurship 


\section{ABSTRACT}

$\mathrm{B}$

usinesses, particularly new businesses, are using the web in diverse ways as they pursue their commercial activities. While newly released data shows overall incidence of a reported website among the population of U.S. businesses was only about a quarter in 2007, young businesses in 2007 were more likely than not to have a website. Using a variety of sources, we expand on the industries and types of business owners that are more likely to report use of websites, email, and online sales. Most of the industry-level trends appeared similar, with firms in Manufacturing, Wholesale Trade, Professional Services, Retail Trade, Financial Services, and Arts, Entertainment, and Recreation tending to have higher proclivities for website use and email but with Professional Services and Financial Services having lower levels of reported Internet sales. Online sales were reported by 6 percent of all U.S. businesses in 2007, compared with more than a quarter of young firms. Additionally, among online sellers, young firms were about twice as likely to generate more than 50 percent of revenues online. In examining differential outcomes from online activities, our analysis shows having a business website had the earliest and most long-lasting effects among startups.

\section{INTRODUCTION}

While institutions such as Gallup have tracked the use of online technologies over time in the general household population, ${ }^{1}$ Internet use by businesses is less examined. Gallup has shown, for instance, that in 2010 the reported daily use of the Internet in the United States was more than one hour for more than half the U.S. population. In this paper, we examine Internet use by U.S. businesses, adopting a definition that focuses on the Internet's role in information exchange as well as in reaching customers for commerce. ${ }^{2}$ We present new research using the Kauffman Firm Survey, a longitudinal dataset that follows 4,928 firms that began operations in 2004 over the 2004-2009 period. We compare this cohort of new firms with information from a variety of government sources on businesses overall. In most cases, we find that new businesses, as studied in the KFS, are adopting e-business activities at higher rates than are existing businesses overall. In some cases, we see evidence that these activities are leading to stronger outcomes for these new businesses. Yet, regardless of outcomes, the prevalence among new businesses seems to indicate that many e-business activities are taken as "givens" for newly created businesses.

As has been documented in other research (Bartelsman, Haltiwanger, \& Scarpetta 2006), new businesses often are conduits for the adoption of higher-productivity business activities within the economy. We see evidence of this in the use of online activities by young firms. While there is some evidence of very concentrated, online-only businesses in the data sources we examined, these businesses are a minority among businesses using

1. http://www.gallup.com/poll/1591/Computers-Internet.aspx.

2. We adopt the definition of e-business as described in Industry Canada's Key Small Business Statistics 2010, which is, "leveraging the Internet for providing or sharing information, or for delivering services, and/or realizing some or all of its revenues from Internet-based transactions and/or the manufacture and sale of Internet-related products." In addition to online purchases and transactions (referred to as e-commerce), e-business includes portfolio management, business planning, and Internet- or intranet-based communication between a business and its clients, suppliers, and other partners (Industry Canada, 2010). E-business can benefit firms in a variety of ways, including the facilitation of production processes, supplier and customer communications, and increasing the firm's presence in the marketplace (ibid). 
the web. There exists a huge variety of adoption and usage rates depending upon the type of business, owner characteristics, industry, and other factors.

Given the dearth of research in this area, we hope this report will stimulate further research about these activities and their influence on our economy, as well as start a serious discussion about how official statistics can be improved to allow for the study of this growing phenomenon. Indeed, our own examination of how businesses use online activities seems remarkably superficial, and yet it is still among the deeper examinations in a large sample of businesses in diverse industries over time.

\section{WHAT TO STUDY}

While Internet use can be examined in many ways, when studying individual firms it becomes more difficult to quantify uses directly in ways that are meaningful across firms. Previous research by Forman et al. (2003) refers to "participation" as using the Internet for general business activities (email, searches) and "enhancement" as adopting Internet technologies to gain comparative advantage in the market (e-commerce). We rely primarily on existing measures in the Kauffman Firm Survey of whether or not a business owner has an email address, if a business has a website, and if a business has any Internet sales (e-commerce). Our measures of email and website use can be thought of as measures of participation, while our e-commerce measure can be seen as engagement because it provides some indication of the intensity of online use or importance to the businesses. Other strands of research, which are not reviewed here, seek to determine the affect of broader measures of Internet connectivity, speed, and other factors in national and regional-level variances in business activity. ${ }^{3}$

\section{PREVALENCE}

Recently released statistics from the Census Bureau's 2007 Survey of Business Owners (SBO) reveal that approximately one quarter of U.S. businesses reported having a business website, while only 6 percent reported any online sales activity (Table 1). ${ }^{4}$ For employer businesses, adoption rates were much higher for websites (40.5 percent) and slightly higher for online sales (about 7 percent). While these are the most recent data and largest sample of businesses the U.S. government has collected on this topic (nearly 1.5 million businesses responded to the 2007 SBO), 2007 was the first year in which the Census Bureau included these questions. Additionally, no information is available tracking the adoption of different practices by businesses over time that might allow for the study of different outcomes. ${ }^{5}$

Table 1

Prevalence of Internet Activities

\begin{tabular}{|l|c|c|}
\multicolumn{1}{c}{} & \multicolumn{1}{c}{ Website } & \multicolumn{1}{c|}{ Internet Sales } \\
\hline All Firms & $24.8 \%$ & $6.0 \%$ \\
\hline Employer Firms Only & $40.5 \%$ & $7.3 \%$ \\
\hline Asian & $26.5 \%$ & $4.8 \%$ \\
\hline Black & $35.2 \%$ & $4.7 \%$ \\
\hline Hispanic & $29.8 \%$ & $4.5 \%$ \\
\hline White & $39.9 \%$ & $7.4 \%$ \\
\hline Female-owned & $39.8 \%$ & $7.4 \%$ \\
\hline
\end{tabular}

Source: Survey of Business Owners, 2007.

However, the SBO data do allow us to delineate website and Internet sales by industry and firm size. And we find substantial differences in the take up rates for each by industry, shown in Table 2, as well as firm size, shown in Table 3. Website use

3. See http://www.itif.org/publications/internet-economy-25-years-after-com for a good example.

4. This figure is inclusive of both the self-employed and employer businesses. A further discussion of the distinctions of employer and nonemployer firms and their relative sizes and influence on the economy is available here: http://www.census.gov/econ/smallbus.html.

5. Our research would seem to suggest that some administrative records collected by the Census Bureau might be useful for tracking adoption of online business activities in more detail. To our knowledge, some administrative forms ask about websites and business email but have not been collected, processed, or tabulated for time series or research use. 
Table 2

Prevalence of Internet Activities by Industry: 2007

\begin{tabular}{|l|r|r|}
\hline \multicolumn{1}{|c|}{ Website } & Internet Sales \\
\hline Total for All Sectors & $40.5 \%$ & $7.3 \%$ \\
\hline $\begin{array}{l}\text { Arts, Entertainment, } \\
\text { and Recreation }\end{array}$ & $58.7 \%$ & $11.7 \%$ \\
\hline Manufacturing & $56.8 \%$ & $17.5 \%$ \\
\hline FIRE & $53.0 \%$ & $7.1 \%$ \\
\hline Wholesale Trade & $50.9 \%$ & $16.1 \%$ \\
\hline Prof., Scientific, and Tech. Serv. & $50.2 \%$ & $5.7 \%$ \\
\hline Retail Trade & $41.4 \%$ & $15.8 \%$ \\
\hline All Other Industries & $38.3 \%$ & $4.8 \%$ \\
\hline $\begin{array}{l}\text { Admin. and Support, } \\
\text { Waste Man. Serv. }\end{array}$ & $38.2 \%$ & $5.5 \%$ \\
\hline Construction & $25.2 \%$ & $1.5 \%$ \\
\hline $\begin{array}{l}\text { Transportation and } \\
\text { Warehousing }\end{array}$ & $25.0 \%$ & $4.9 \%$ \\
\hline
\end{tabular}

Source: Employer firms only. Survey of Business Owners, 2007.

ranged from a low of one quarter of Transportation, Warehousing, and Construction firms to highs of 50 percent to 60 percent of firms in Manufacturing; Arts, Entertainment, and Recreation; Wholesale;
Table 3

Prevalence of Internet Activities by Employment Size: 2007

\begin{tabular}{|c|c|c|}
\multicolumn{1}{c}{} & \multicolumn{1}{c}{ Website } & \multicolumn{1}{c|}{ Internet Sales } \\
\hline All Employer Firms & $40.5 \%$ & $7.3 \%$ \\
\hline 1 to 4 employees & $31.4 \%$ & $5.9 \%$ \\
\hline 5 to 9 employees & $43.7 \%$ & $7.5 \%$ \\
\hline 10 to 19 employees & $53.5 \%$ & $8.8 \%$ \\
\hline 20 to 49 employees & $64.8 \%$ & $10.9 \%$ \\
\hline 50 to 99 employees & $75.1 \%$ & $13.9 \%$ \\
\hline 100 to 499 employees & $81.4 \%$ & $15.5 \%$ \\
\hline $500+$ employees & $89.7 \%$ & $20.9 \%$ \\
\hline
\end{tabular}

Source: Employer firms only. Survey of Business Owners, 2007.

Finance, Insurance, and Real Estate (FIRE); and Professional, Scientific, and Technical Services (see Figure 1). The share of firms that had Internet sales in 2007 was much lower regardless of industry, ranging from a low of 1.5 percent for Construction to a high of 17.5 percent of Manufacturing. Wholesale, Retail, and Arts, Entertainment, and Recreation also had double-digit readings for Internet sales.

Figure 1

Prevalence of Internet Activities by Industry: 2007

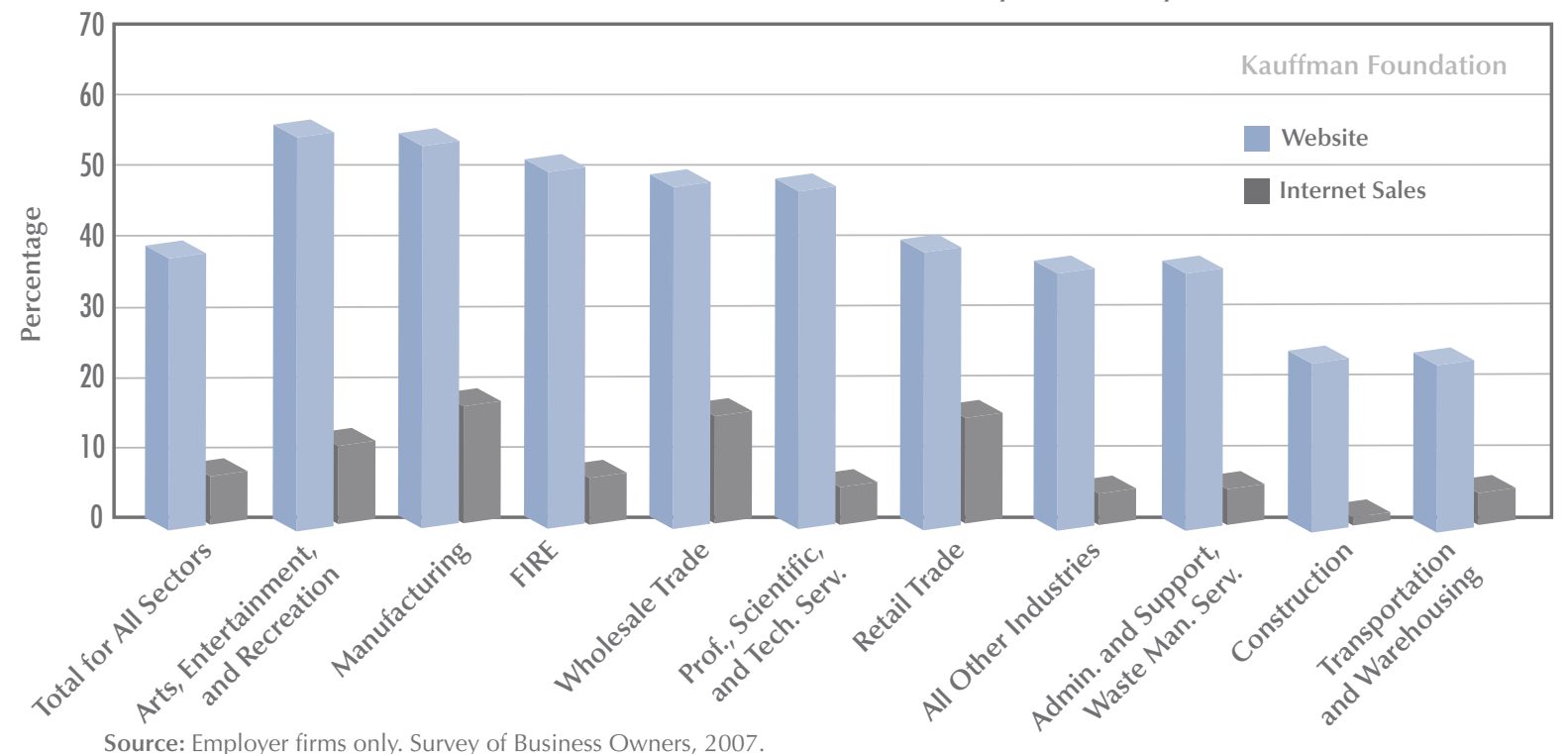


Figure 2

Prevalence of Internet Activities by Employment Size: 2007

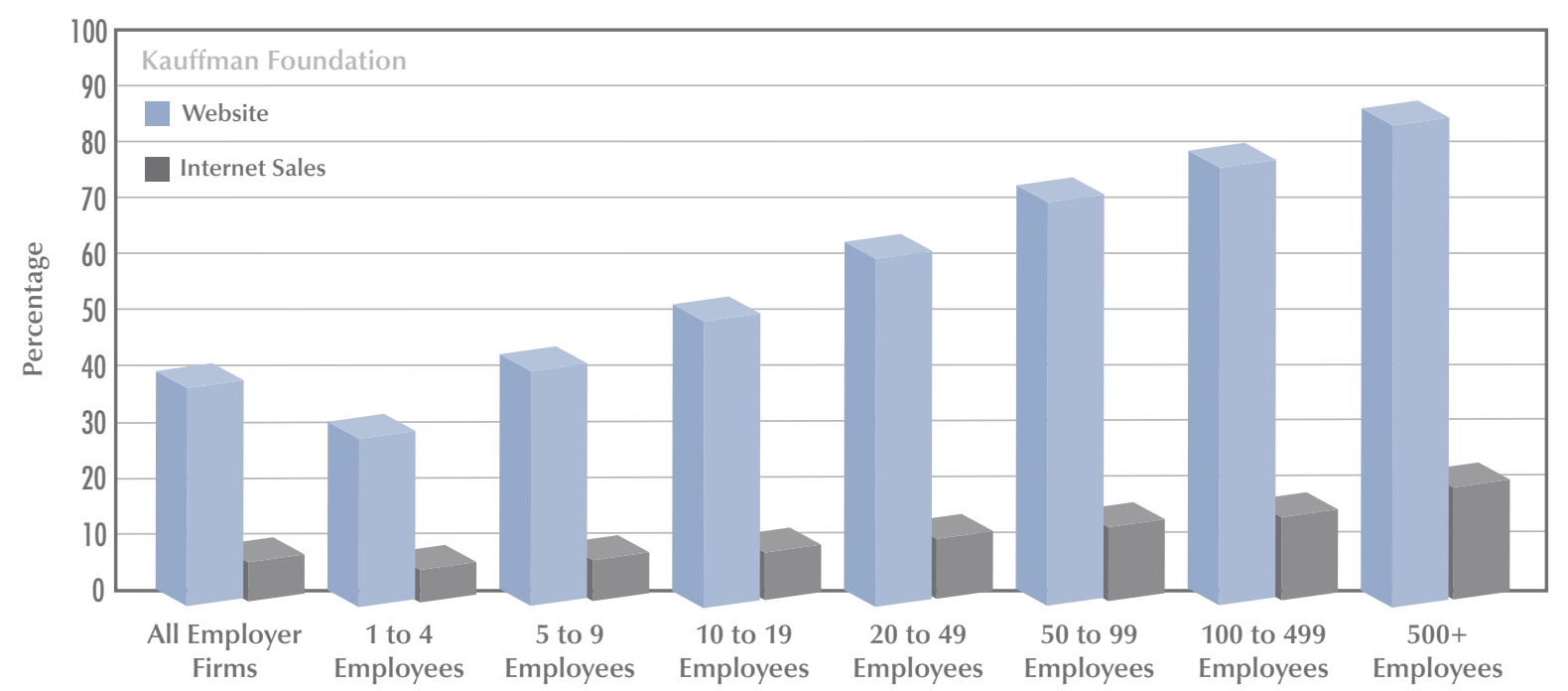

Source: Employer firms only. Survey of Business Owners, 2007.

As shown in Figure 2, the prevalence of both websites and Internet sales were increasing in firm size, with about 90 percent of large firms reporting a website, compared with less than a third of the smallest employer firms, those with one to four employees. Likewise, more than 20 percent of large firms indicated Internet sales, compared with around just 5 percent for firms with one to four employees. ${ }^{6}$

Data provided by annual surveys from Manufacturers, Wholesale Trade, Retail Trade, and Selected Services, also from the U.S. Census Bureau but with smaller samples of industries and small businesses than the Survey of Business Owners, show that e-commerce sales growth has outpaced overall sales growth over the 2004-2009 period. As shown in Table 4, e-commerce sales reached $\$ 1,862$ billion in Manufacturing by 2009, an increase of
87 percent over the 2004-2009 period, compared with an increase of just 3 percent of total sales in Manufacturing (Table 5). The growth in e-commerce sales was even more dramatic in Retail Trade, nearly doubling over the 2004-2009 period, compared with an increase of less than 5 percent for Retail sales overall. Yet, the e-commerce sales of $\$ 145$ billion in Retail were just 4 percent of the total Retail sales. E-commerce sales in Selected Services totaled $\$ 153$ billion by 2009, an increase of more than 86 percent over the 2004-2009 period. Total sales in this industry increased about 22 percent over the same period. Finally, e-commerce in Wholesale Trade increased less than 20 percent over the 2004-2009 period to $\$ 1,211$ billion, compared with an increase of just 6.5 percent of Wholesale Trade sales overall.

6. In 2006, the National Federation of Independent Businesses found 51 percent of businesses with less than 250 employees (but which had employees) had a website; only about a fifth of these websites were reportedly equipped to handle financial transactions. They also found that the "single most important means of advertising for small, employing businesses are the Internet (16 percent), word-of-mouth (15 percent), newspapers (15 percent), and direct mail (14 percent)." (Hills and Hultman, 2006) 
Table 4

U.S. Shipments, Sales, Revenues, and E-Commerce: 2004-2009

(Shipments, Sales, and Revenues are shown in millions of dollars)

\begin{tabular}{|c|c|c|c|c|c|}
\hline & & $\begin{array}{l}\text { Manufacturing } \\
\text { Shipments }^{1}\end{array}$ & $\begin{array}{c}\text { Wholesale } \\
\text { Trade Sales } \\
\text { (Including MSBOs²) }\end{array}$ & $\begin{array}{l}\text { Retail Trade } \\
\text { Sales }^{3}\end{array}$ & $\begin{array}{c}\text { Selected } \\
\text { Service Revenues }\end{array}$ \\
\hline \multirow[t]{3}{*}{2009} & Total & $4,436,196$ & $5,165,629$ & $3,638,471$ & $6,773,726$ \\
\hline & E-commerce & $1,862,493$ & $1,211,219$ & 145,214 & 153,007 \\
\hline & Percent of Total & 42.0 & 23.4 & 4.0 & 2.3 \\
\hline \multirow[t]{3}{*}{2008} & Total & $5,468,093$ & $6,162,159$ & $3,952,933$ & $6,886,995$ \\
\hline & E-commerce & $2,170,818$ & $1,311,496$ & 142,281 & 149,668 \\
\hline & Percent of Total & 39.7 & 21.3 & 3.6 & 2.2 \\
\hline \multirow[t]{3}{*}{2007} & Total & $5,338,307$ & $5,888,989$ & $4,005,798$ & $6,858,630$ \\
\hline & E-commerce & $1,879,424$ & $1,297,751$ & 138,145 & 131,553 \\
\hline & Percent of Total & 35.2 & 22.0 & 3.4 & 1.9 \\
\hline \multirow[t]{3}{*}{2006} & Total & $5,015,553$ & $5,612,133$ & $3,880,136$ & $6,434,839$ \\
\hline & E-commerce & $1,566,799$ & $1,242,098$ & 114,912 & 110,463 \\
\hline & Percent of Total & 31.2 & 22.1 & 3.0 & 1.7 \\
\hline \multirow[t]{3}{*}{2005} & Total & $4,742,076$ & $5,262,720$ & $3,696,691$ & $5,973,700$ \\
\hline & E-commerce & $1,343,852$ & $1,173,757$ & 92,804 & 93,299 \\
\hline & Percent of Total & 28.3 & 22.3 & 2.5 & 1.6 \\
\hline \multirow[t]{3}{*}{2004} & Total & $4,308,971$ & $4,851,241$ & $3,480,430$ & $5,565,502$ \\
\hline & E-commerce & 996,174 & $1,020,854$ & 74,175 & 82,103 \\
\hline & Percent of Total & 23.1 & 21.0 & 2.1 & 1.5 \\
\hline
\end{tabular}

Note: Estimates are not adjusted for price changes and are subject to revision. For additional information on confidentiality protection, sampling error, sample design, and definitions see http://www.census.gov/eos/www/sm.html.

1. Estimates include data only for businesses with paid employees.

2. Manufacturers' Sales Branches and Offices.

3. Estimates include data for businesses with or without paid employees.

4. Estimates include data for businesses with paid employees except for Accommodation and Food Services, which also includes businesses without paid employees. Includes NAICS 4849x (Selected Transportation and Warehousing), NAICS 51 (Information), NAICS 523x (Selected Finance), NAICS 532 (Rental and Leasing Services), NAICS 54 (Selected Professional, Scientific, and Technical Services), NAICS 56 (Administrative and Support and Waste Management and Remediation Services), NAICS 62 (Health Care and Social Assistance Services), NAICS 71 (Arts, Entertainment, and Recreation Services), NAICS 72 (Accommodation and Food Services), and NAICS 81 (Selected Other Services). Estimates for 2000-2003 are not comparable due to the change in the 2002 NAICS and detailed NAICSlevel inclusions. Estimates for 2002 and 2003 exclude NAICS 561730 (Landscaping Services), NAICS 54132 (Landscape Architectural Services), NAICS 54194 (Veterinary Services), and NAICS 81291 (Pet Care Services).

Source: U.S. Census Bureau, 2009 Annual Survey of Manufacturers, 2007 Economic Census-Manufacturing, 2009 Annual Wholesale Trade Survey, 2009 Annual Retail Trade Survey, and 2009 Service Annual Survey.

Table 5

U.S. Shipments, Sales, Revenues, and E-Commerce Growth Rates (2004-2009)

\begin{tabular}{|l|c|c|}
\multicolumn{1}{c|}{} & \multicolumn{1}{c}{$\begin{array}{c}\text { E-Commerce } \\
\text { Sales }\end{array}$} & \multicolumn{1}{c|}{$\begin{array}{c}\text { Total } \\
\text { Sales }\end{array}$} \\
\hline Retail Trade & $95.8 \%$ & $4.5 \%$ \\
\hline Manufacturing Shipments & $87.0 \%$ & $3.0 \%$ \\
\hline Selected Services & $86.4 \%$ & $21.7 \%$ \\
\hline Wholesale Trade & $18.6 \%$ & $6.5 \%$ \\
\hline
\end{tabular}

Source: U.S. Census Bureau, 2009 Annual Survey of Manufacturers, 2007 Economic Census-Manufacturing, 2009 Annual Wholesale Trade Survey, 2009 Annual Retail Trade Survey, and 2009 Service Annual Survey. 
Looking at the share of e-commerce sales as a percentage of total sales from 2004-2009 reveals some interesting trends. While e-commerce made up just about 2 percent of Retail Sales and Selected Services sales in 2004, it made up 21 percent of wholesale sales and 23 percent of manufacturing sales (Table 4). By 2009, the figures were similar for Retail (4 percent) and Services (2.3 percent), but had reached more than 23 percent for Wholesale Trade and 42 percent for Manufacturing. As can be seen in Figure 3, the importance of e-commerce in Retail and Services is quite small and has changed very little, while it is quite significant in the Wholesale and Manufacturing industries. Its relative importance in Wholesale hasn't changed very much over the 2004-2009 period, but it has nearly doubled in Manufacturing.

While we can't compare the United States case well internationally, one comparison, with Canada, is possible and quite similar in trend. The vast majority of firms have Internet access, fewer businesses have websites, and even fewer still have any Internet sales. And, while they each are growing slightly, they have been remarkably stable over the 2001-2007 period (see Figure 4). Unfortunately, the Canadian data do not allow us to break firms out by firm age, so these findings apply to existing firms overall and not just new firms. However, as shown in Table 6, we do see that each of these take up rates are increasing in firm size, with larger firms much more likely than smaller firms to make use of the Internet, have a website, or sell their products/ services through the Internet.

Turning back to the United States, the Kauffman Firm Survey data are unique in that a cohort of 4,928 firms that began operations in 2004 are followed over the 2004-2009 period. ${ }^{7}$ So, while we can only comment on these young firms as they age, we are able to track adoption of different practices in this population over time and also present the data on online activities alongside other information that also is tracked annually, such as

Figure 3

\section{E-Commerce Sales as a Percentage of Total Sales, United States: 2004-2009}

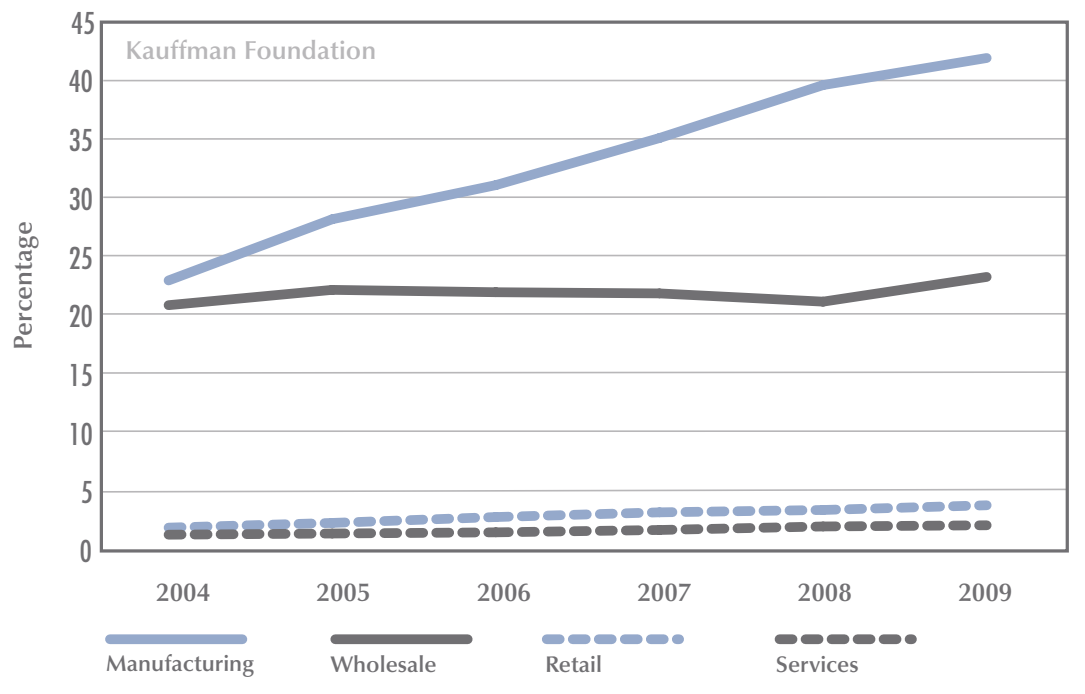

Source: U.S. Census Bureau, 2009 Annual Survey of Manufacturers, 2007 Economic Census-Manufacturing, 2009 Annual Wholesale Trade Survey, 2009 Annual Retail Trade Survey, and 2009 Service Annual Survey.

7. The final KFS panel will be eight years. Additional information is available at http://www.kauffman.org/kfs. 
Figure 4

\section{Percent of Firms with Website, Internet Access, and Internet Sales, Canada: 2001-2007}

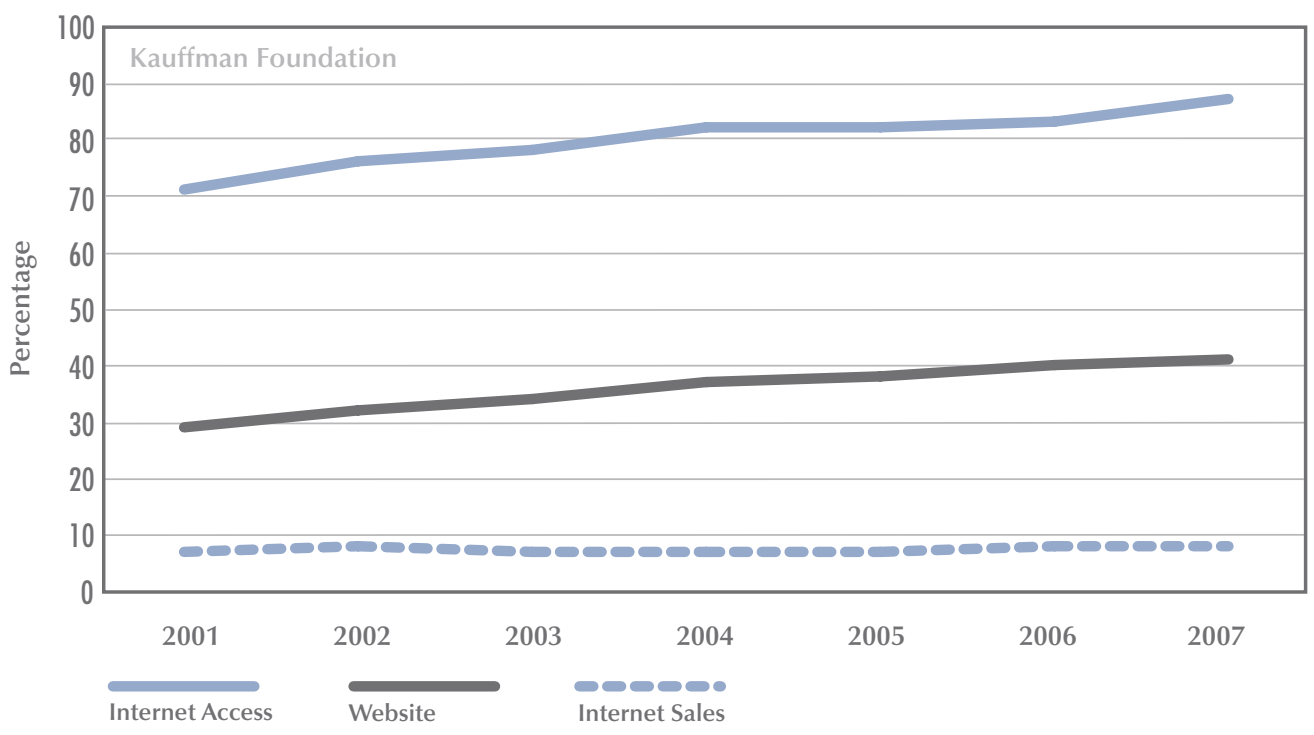

Source: Statistics Canada, Survey of Electronic Commerce and Technology (SECT), 2008.

Table 6

Website, Internet Access, and Internet Sales for Canadian Firms by Firm Size (Percent): 2001-2007

\begin{tabular}{|c|c|c|c|c|c|c|c|}
\hline Internet Access & 2001 & 2002 & 2003 & 2004 & 2005 & 2006 & 2007 \\
\hline Small & 68 & 73 & 76 & 79 & 79 & 81 & 85 \\
\hline Medium & 91 & 92 & 94 & 96 & 96 & 96 & 95 \\
\hline Large & 94 & 99 & 97 & 99 & 98 & 99 & 99 \\
\hline All & 71 & 76 & 78 & 82 & 82 & 83 & 87 \\
\hline \multicolumn{8}{|l|}{ Website } \\
\hline Small & 24 & 27 & 29 & 32 & 33 & 35 & 36 \\
\hline Medium & 57 & 62 & 66 & 69 & 70 & 71 & 74 \\
\hline Large & 74 & 77 & 77 & 79 & 82 & 89 & 90 \\
\hline All & 29 & 32 & 34 & 37 & 38 & 40 & 41 \\
\hline \multicolumn{8}{|l|}{ Internet Sales } \\
\hline Small & 6 & 7 & 6 & 7 & 6 & 7 & 7 \\
\hline Medium & 12 & 13 & 14 & 12 & 10 & 12 & 13 \\
\hline Large & 15 & 16 & 16 & 13 & 16 & 21 & 22 \\
\hline All & 7 & 8 & 7 & 7 & 7 & 8 & 8 \\
\hline
\end{tabular}

Note: Statistics Canada's Survey of Electronic Commerce and Technology (SECT), on which these data are based, defines small firms as having fewer than 20 employees, medium-sized firms as having between 20 and 99 employees, and large firms as having 100 employees or more for all industries except manufacturing. The upper limit for the medium-sized category in the manufacturing industry is 499 employees, whereas firms with 500 employees or more are defined as large.

Source: Statistics Canada, Survey of Electronic Commerce and Technology (SECT), 2008. 
Figure 5

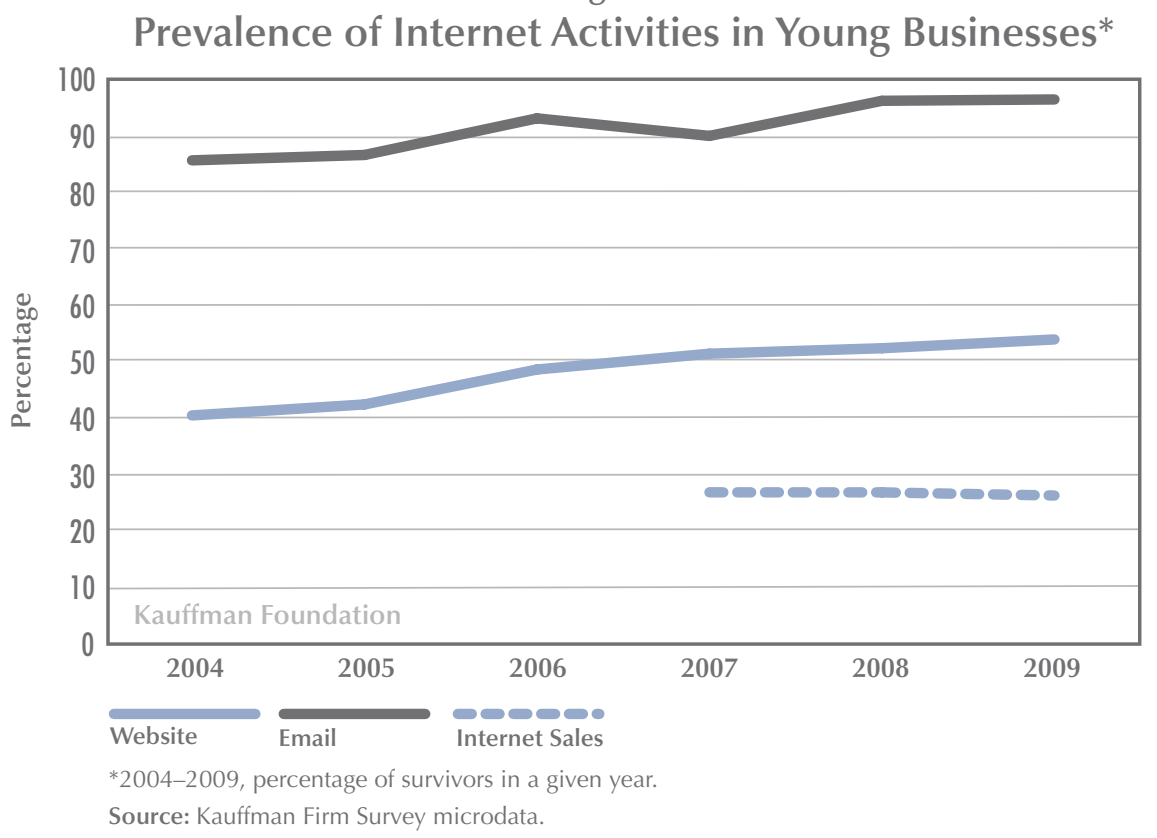

the financing activities of the businesses, ownership structures, and employment. In Figure 5, we can see that, from the beginning, and almost ubiquitously over time, new business owners report using email. This started just below 90 percent for the full sample in 2004 and was approximately 97 percent for firms still surviving in 2009.

Business websites appear more common in new businesses than in the average U.S. business, with

40 percent of new businesses in 2004 reporting having a business website, compared with the quarter of all firms that the Census Bureau found in 2007. For the full KFS sample, including employer and nonemployer firms, having a business website became steadily more prevalent over time, with 54.1 percent of surviving firms reporting a business website by 2009 (see Table 7).

Table 7

Prevalence of Internet Activities in Young Businesses*

\begin{tabular}{|c|c|c|c|}
\hline Year & Website & Email & Internet Sales \\
\hline 2004 & $40.5 \%$ & $86.0 \%$ & N/A \\
\hline 2005 & $42.5 \%$ & $87.0 \%$ & N/A \\
\hline 2006 & $48.7 \%$ & $93.5 \%$ & $26.8 \%$ \\
\hline 2007 & $51.5 \%$ & $90.4 \%$ & $26.8 \%$ \\
\hline 2008 & $52.5 \%$ & $96.6 \%$ & $26.2 \%$ \\
\hline 2009 & $54.1 \%$ & $96.9 \%$ & \\
\hline
\end{tabular}

*2004-2009, percentage of survivors in a given year.

Source: Kauffman Firm Survey microdata. 
In 2007, new questions were added to the KFS questionnaire to gather data on the sales activities of the sample. While these questions show a much higher incidence of Internet sales (or e-commerce) among our sample of new firms-approximately 27 percent-compared with a 6 percent for U.S. businesses in general (Table 1), the reported incidence of Internet sales has remained steady in the KFS sample over the 2007-2009 period. Such steadiness in the sample, at a time of relative economic turmoil, would seem to indicate that these online sales activities were adopted early in the business lifecycles, likely since birth or shortly thereafter. Such information would seem to point toward an important way in which businesses being started today are different from existing businesses in their organization and use of resources to drive higher productivity practices.

\section{Inside Businesses}

In Table 8, we look deeper at the types of young businesses that are using online activities. While more than 80 percent of business owners report an email in all cuts of the data presented here, indicating the wide adoption of email by new business owners, business owners in rural locations seemed to lag slightly. Having a business website was reported with a greater degree of variation, with higher incidences being reported by businesses that were incorporated, employers, not based out of the home, operating in an urban location, and which had multiple business owners. In looking at owner characteristics, businesses that had websites were more prevalent among Asian-owned businesses (50.6 percent), owners who had college (50.5 percent) or graduate degrees (46 percent), and owners with previous startup experience (45.7 percent).
The incidence of Internet sales was more consistent than a business website was across firms. While businesses not operating out of the home reported the highest incidence here (38 percent), all breakouts were above 30 percent-even the lowest rate, which was among businesses that had 50 percent or more of their sales to government customers. In terms of owner characteristics, Asianowned businesses again reported higher prevalence of Internet sales (43.3 percent), along with owners with previous startup experience (40.7 percent).

The prevalence of a website, an email, and Internet sales in young firms by the race/ethnicity of the primary owner is shown in Figure 6. While Blacks and Hispanics lag behind Whites and Asians, the drop is more significant in terms of having a website and having Internet sales than in email. ${ }^{8}$

Turning our analysis to differences across industries, the highest prevalence of having a website among new businesses at startup came among high-tech firms. ${ }^{9}$ It should be noted that high tech, as shown here, is a composite of portions of different industries shown in the other categories in Table 9. Having a website in the first year of operations was most common in Manufacturing and Wholesale Trade (both about 50 percent), but also prevalent in Professional Services; Retail Trade; Finance, Insurance, and Real Estate (FIRE); and Arts, Entertainment, and Recreation. Similar patterns can be seen in the Survey of Business Owners' data, with Arts, Entertainment, and Recreation having the highest website prevalence (58.7 percent), and Manufacturing, FIRE, Wholesale Trade, and Professional, Scientific, and Technical Services all having prevalence rates above 50 percent (Table 2).

In terms of Internet sales, our KFS findings show similar patterns to the data from the SBO and the annual Census Bureau industry surveys mentioned previously. Internet sales were most infrequent

8. Similar information is available in the SBO but is not presented here.

9. We classify subsets of firms in high-technology industries in two ways. Following Chapple, et al. (2004), we identify industries that are considered technology employers, that is, industries where employment of these occupations exceeds three times the national averages of 3.33 percent or 9.98 percent. In addition, we identify industries that are technology generators, which are defined by the NSF's Survey of Industrial Research and Development as industries that exceed the U.S. average for both research and development expenditures for employee $(\$ 11,972)$ and the proportion of full-timeequivalent R\&D scientists and engineers in the industry workforce (5.9 percent). We classify firms as high tech if they fall into at least one of these two categories. 
Table 8

Prevalence of Internet Activities in Young Businesses

by Owner and Firm Characteristics

\begin{tabular}{|c|c|c|c|}
\hline & Website & Email & Internet Sales* \\
\hline \multicolumn{4}{|l|}{ Firm Characteristics } \\
\hline Incorporated & $45.3 \%$ & $88.7 \%$ & $34.4 \%$ \\
\hline Sole Proprietorship or Partnership & $33.8 \%$ & $82.2 \%$ & $35.7 \%$ \\
\hline Employer Firm & $46.3 \%$ & $88.3 \%$ & $37.2 \%$ \\
\hline Nonemployer Firm & $36.9 \%$ & $84.6 \%$ & $33.6 \%$ \\
\hline Home-based & $36.4 \%$ & $86.3 \%$ & $31.9 \%$ \\
\hline Not Home-based & $44.5 \%$ & $85.7 \%$ & $38.0 \%$ \\
\hline High Credit Score & $45.9 \%$ & $90.2 \%$ & $32.5 \%$ \\
\hline Med/Low Credit Score & $39.8 \%$ & $85.4 \%$ & $35.4 \%$ \\
\hline High-Tech Industry & $65.7 \%$ & $95.9 \%$ & $32.7 \%$ \\
\hline Urban Location & $42.8 \%$ & $87.4 \%$ & $35.8 \%$ \\
\hline Rural Location & $28.7 \%$ & $79.1 \%$ & $30.5 \%$ \\
\hline Individuals are $50 \%+$ of Sales & $38.1 \%$ & $84.3 \%$ & $35.2 \%$ \\
\hline Businesses are $50 \%+$ of Sales & $42.8 \%$ & $88.8 \%$ & $33.3 \%$ \\
\hline Government is $50 \%+$ of Sales & $39.1 \%$ & $88.9 \%$ & $30.0 \%$ \\
\hline Multi-Owner Firms & $45.2 \%$ & $88.8 \%$ & $36.9 \%$ \\
\hline Single-Owner Firms & $38.0 \%$ & $84.5 \%$ & $33.9 \%$ \\
\hline \multicolumn{4}{|l|}{ Owner Characteristics } \\
\hline \multicolumn{4}{|l|}{ Race/Ethnicity } \\
\hline Black & $31.5 \%$ & $83.4 \%$ & $31.2 \%$ \\
\hline Hispanic & $33.5 \%$ & $87.1 \%$ & $33.2 \%$ \\
\hline Asian & $50.6 \%$ & $92.0 \%$ & $43.3 \%$ \\
\hline White & $41.5 \%$ & $86.4 \%$ & $35.0 \%$ \\
\hline Other & $44.5 \%$ & $82.9 \%$ & $38.3 \%$ \\
\hline \multicolumn{4}{|l|}{ Gender } \\
\hline Female & $38.9 \%$ & $86.6 \%$ & $34.3 \%$ \\
\hline Male & $41.3 \%$ & $86.1 \%$ & $35.1 \%$ \\
\hline \multicolumn{4}{|l|}{ Education and Startup Experience } \\
\hline College Degree & $50.5 \%$ & $90.2 \%$ & $36.8 \%$ \\
\hline Graduate Degree & $46.0 \%$ & $91.6 \%$ & $35.6 \%$ \\
\hline Previous Startup Experience & $45.7 \%$ & $89.2 \%$ & $40.7 \%$ \\
\hline ALL FIRMS & $40.5 \%$ & $86.0 \%$ & $35.0 \%$ \\
\hline
\end{tabular}

*Firms that had Internet sales in any of the years 2007-2009 and only those that survived until at least 2007. Website and email from 2004. Source: Kauffman Firm Survey microdata. 
Figure 6

\section{Prevalence of Internet Activities in Young Businesses by Primary Owner/Ethnicity}

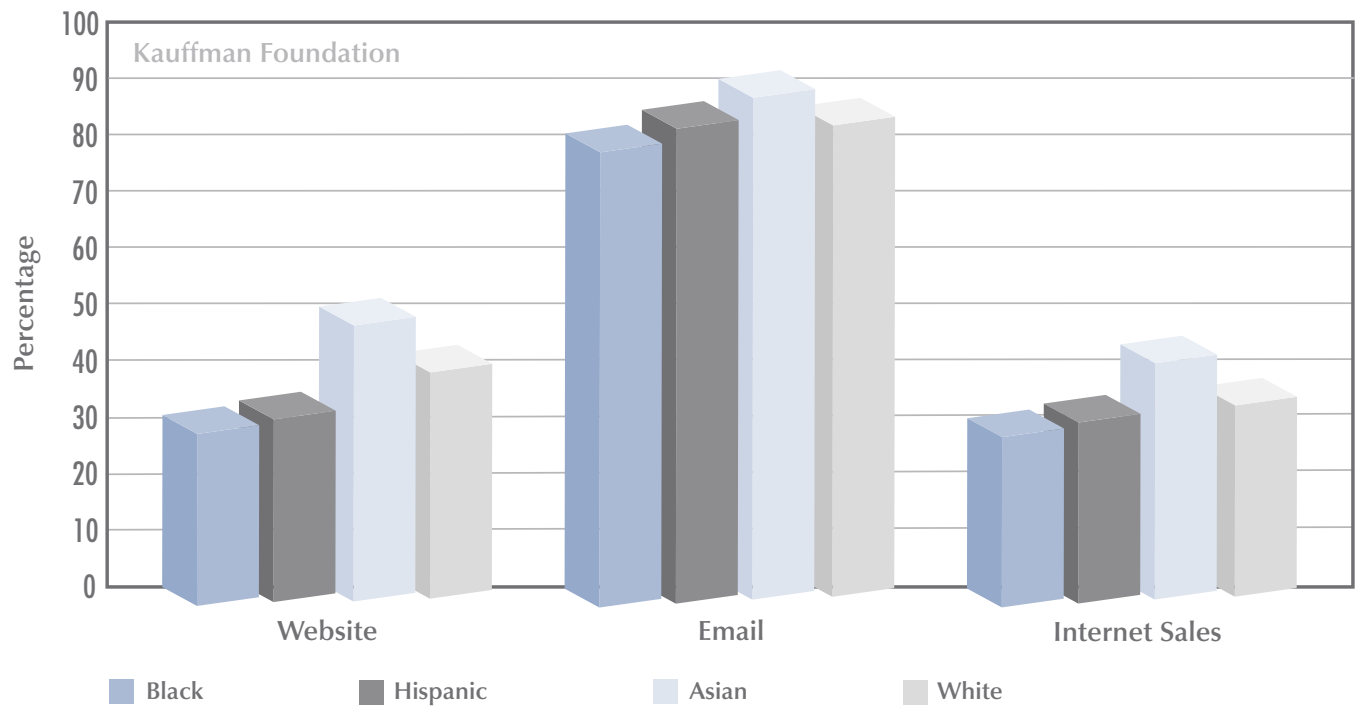

Note: Firms that had Internet sales in any of the years 2007-2009 and only those that survived until at least 2007. Website and email from 2004

Source: Kauffman Firm Survey microdata.

Table 9

Prevalence of Internet Activities in Young Businesses by Industry

\begin{tabular}{|c|c|c|c|}
\hline & Website & Email & Internet Sales* \\
\hline All Firms & $40.5 \%$ & $86.0 \%$ & $35.0 \%$ \\
\hline High-Tech Industries & $65.7 \%$ & $95.9 \%$ & $32.7 \%$ \\
\hline Manufacturing & $59.8 \%$ & $88.5 \%$ & $50.5 \%$ \\
\hline Wholesale Trade & $54.5 \%$ & $89.1 \%$ & $55.7 \%$ \\
\hline Professional, Management, Educ. Services & $48.3 \%$ & $91.8 \%$ & $29.7 \%$ \\
\hline Retail Trade & $46.0 \%$ & $85.2 \%$ & $51.6 \%$ \\
\hline Finance, Insurance, and Real Estate & $44.0 \%$ & $91.2 \%$ & $33.7 \%$ \\
\hline Arts, Entertainment, Rec. & $42.9 \%$ & $84.3 \%$ & $48.3 \%$ \\
\hline $\begin{array}{l}\text { Admin. and Support, Waste, Remed. Services, } \\
\text { Health Care, Social Assistance }\end{array}$ & $33.0 \%$ & $88.3 \%$ & $25.7 \%$ \\
\hline All Other Industries & $28.8 \%$ & $78.0 \%$ & $28.6 \%$ \\
\hline Transportation/Warehousing & $23.7 \%$ & $83.3 \%$ & $40.6 \%$ \\
\hline Construction & $21.3 \%$ & $74.3 \%$ & $17.8 \%$ \\
\hline $\mathrm{n}$ & 4,099 & 4,099 & 2,724 \\
\hline
\end{tabular}

*Firms that had Internet sales in any of the years 2007-2009 and only those that survived until at least 2007. Website and email from 2004. Source: Kauffman Firm Survey microdata. 


\section{Figure 7}

\section{Internet Sales as a Percentage of Total Sales*}

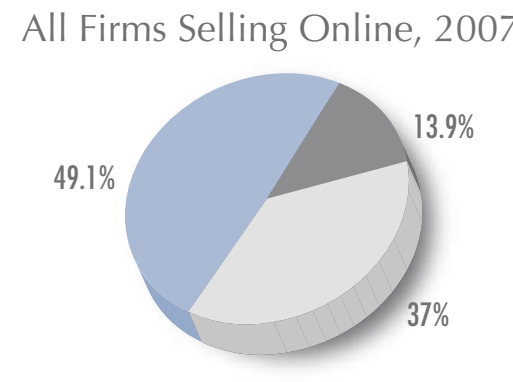

Young Firms Selling Online, 2007

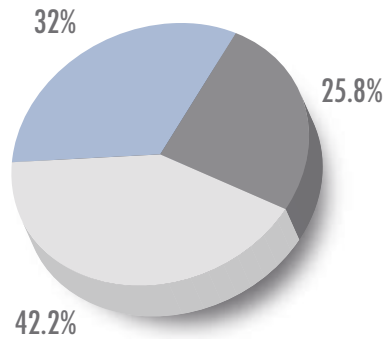

Kauffman Foundation

Online sales less than $5 \%$ revenues $\quad$ Online sales $5 \%-50 \%$

Online sales $51 \%-100 \% *$

*SBO category breaks at 5\%-49\% and $50 \%-100 \%$

Source: Employee Firms Only, Survey of Business Owners, 2007;

Kauffman Firm Survey microdata, 2007

among Construction businesses (17.8 percent). More than half of all firms surviving until at least 2007 in Manufacturing, Wholesale, and Retail Trade had some Internet sales over the 2007-2009 period. Yet, the relative importance also varied by industry. Internet sales accounted for more than half of total sales in only about one quarter of firms with any
Internet sales. For nearly a third of businesses that had some Internet sales from 2007-2009, Internet sales made up less than five percent of total sales. These patterns clearly show more Internet sales intensity among younger firms. As Figure 7 shows, data from the 2007 SBO show that about half of employer firms with any Internet sales made less 
than 5 percent of their revenues through Internet sales and only about 14 percent made more than 50 percent of their revenues through Internet sales. The KFS firms rely more on Internet sales than do U.S. firms overall. More than 37 percent of firms in Retail Trade made more than half of their sales through the Internet, while only about 11 percent of construction firms did so. Manufacturing and Wholesale each had about 25 percent of firms making up more than 50 percent of their sales through the Internet (Table 10).

\section{Financing}

In Table 11, we examine the startup capital decisions of businesses in the KFS sample in their startup year, separating out businesses that had a website, used email, or had Internet sales. In general, the use of each of these online activities by a new business was associated with having overall higher levels of financial capitalization at birth (almost \$55,000 more if a firm had a website, almost $\$ 46,000$ more if the business owner had an email, and more than $\$ 25,000$ if the firm later reported Internet sales). We saw the online activities examined here as an indicator of higher intensity of work on a new business, as shown earlier with higher average hours put in by the business owner in Table 8; the higher levels of financial capital injections at the beginning of business operations also would seem to support this notion. Where this contradicts common perception and discussion about the impact of the Internet on business activities is in the sense that it is common to associate online activities with cheaper business startup costs. However, this "cheaper-to-start" narrative usually is considering outsourcing, use of free online technology tools, and decreasing costs of computers and technology, all of which are driving down startup costs, but which we are not able to track in our sample.

In addition to the higher levels of capital injected, there appear to be some interesting differences in financial composition associated with firms that have business websites. These firms were more likely to get outside equity, such as angel investments

Table 10

Internet Sales as a Percentage of Total Sales in Young Firms by Industry: 2007* (only firms with some Internet sales)

\begin{tabular}{|c|c|c|c|c|c|}
\hline & Less than $5 \%$ & $5 \%-25 \%$ & $26 \%-50 \%$ & $51 \%-75 \%$ & $76 \%-100 \%$ \\
\hline All Firms & $32.1 \%$ & $31.3 \%$ & $10.8 \%$ & $8.0 \%$ & $17.8 \%$ \\
\hline $\begin{array}{l}\text { Admin. \& Support, Waste, } \\
\text { Remed. Services, Health Care, } \\
\text { Social Assistance }\end{array}$ & $21.6 \%$ & $37.2 \%$ & $13.2 \%$ & $8.6 \%$ & $19.4 \%$ \\
\hline Arts, Entertainment, Rec. & $16.9 \%$ & $26.1 \%$ & $27.8 \%$ & $16.9 \%$ & $12.3 \%$ \\
\hline Construction & $45.6 \%$ & $43.5 \%$ & $0.0 \%$ & $0.0 \%$ & $10.9 \%$ \\
\hline $\begin{array}{l}\text { Finance, Insurance, } \\
\text { and Real Estate }\end{array}$ & $30.8 \%$ & $39.9 \%$ & $8.0 \%$ & $4.7 \%$ & $16.6 \%$ \\
\hline Manufacturing & $38.9 \%$ & $35.8 \%$ & $0.7 \%$ & $13.0 \%$ & $11.7 \%$ \\
\hline $\begin{array}{l}\text { Professional, Management, } \\
\text { Educ. Services }\end{array}$ & $31.6 \%$ & $34.6 \%$ & $11.9 \%$ & $7.5 \%$ & $14.4 \%$ \\
\hline Retail Trade & $26.1 \%$ & $27.1 \%$ & $9.5 \%$ & $11.1 \%$ & $26.3 \%$ \\
\hline Transportation/Warehousing & $46.5 \%$ & $14.4 \%$ & $16.2 \%$ & $8.1 \%$ & $14.8 \%$ \\
\hline Wholesale Trade & $39.7 \%$ & $18.2 \%$ & $18.2 \%$ & $3.1 \%$ & $20.7 \%$ \\
\hline All Other Industries & $45.1 \%$ & $29.9 \%$ & $10.7 \%$ & $2.3 \%$ & $12.0 \%$ \\
\hline
\end{tabular}

* Only those that survived until at least 2007.

Source: Kauffman Firm Survey microdata. 
Table 11

Distribution of Startup Capital in Young Firms by Use of Internet Activities

\begin{tabular}{|c|c|c|c|c|c|c|}
\hline & \multicolumn{2}{|c|}{ Website } & \multicolumn{2}{|c|}{ Email } & \multicolumn{2}{|c|}{ Internet Sales* } \\
\hline & Yes & No & Yes & No & Yes & No \\
\hline Owner Equity & $27.2 \%$ & $29.2 \%$ & $28.1 \%$ & $29.1 \%$ & $28.1 \%$ & $25.3 \%$ \\
\hline Insider Equity & $1.4 \%$ & $2.0 \%$ & $1.7 \%$ & $0.9 \%$ & $1.2 \%$ & $1.3 \%$ \\
\hline Outsider Equity & $24.0 \%$ & $6.9 \%$ & $15.8 \%$ & $15.4 \%$ & $16.9 \%$ & $18.5 \%$ \\
\hline Owner Debt & $4.2 \%$ & $4.2 \%$ & $4.3 \%$ & $3.7 \%$ & $4.8 \%$ & $3.4 \%$ \\
\hline Insider Debt & $5.6 \%$ & $6.0 \%$ & $6.1 \%$ & $2.7 \%$ & $4.7 \%$ & $5.3 \%$ \\
\hline Outsider Debt & $37.6 \%$ & $51.8 \%$ & $44.1 \%$ & $48.2 \%$ & $44.3 \%$ & $46.1 \%$ \\
\hline Total Financial Capital & $\$ 148,500$ & $\$ 93,593$ & $\$ 122,271$ & $\$ 76,332$ & $\$ 139,130$ & $\$ 113,566$ \\
\hline $\mathrm{n}$ & 934 & 1,790 & 3,576 & 523 & 934 & 1,790 \\
\hline
\end{tabular}

*Firms that had Internet sales in any of the years 2007-2009 and only those that survived until at least 2007. Website and email from 2004.

Source: Kauffman Firm Survey microdata.

or venture capital, substituting this for outside debt injections (formal debt financing from banks). Business email and online sales activity didn't affect the financial composition of the startups in our sample.

\section{Outcomes}

With the KFS panel data, we can examine some outcomes in the different samples of firms that used websites, email, or had online sales activity. Here, as seen in the financing composition, the presence of a website at firm birth seemed to have the biggest differential in terms of outcomes among young businesses in our sample. In Table 12, we see that firms starting with a website tended to start bigger, with 2.3 employees on average (vs. 1.6 in firms without a website) and grew faster over time to an average of 4.7 employees in 2009 (compared with an average of 2.9 employees for firms that didn't start with a website). Business survival was higher for the group starting with websites, and financial assets started and stayed larger over the period. Revenues were larger in the startup year, as well as at the end of the period, for firms with a website (30 percent), which ended 2009 more than 60 percent ahead of businesses that didn't start with a website (see Figure 8).

Having a business email at startup seems to have had more mixed associations. The group that had emails showed higher survival rates through 2009 and early growth in employment, but later stagnated. Over time, firms without email at their start showed steadier continued growth in employment, on average, and similar trends in steadier asset accumulation. The early employment growth among firms starting with business emails was in parallel to a quick rise and then stagnation in revenues.

In terms of online sales activity, dividing the sample into two groups, those that had online sales during 2007-2009 and those that did not, does not prove particularly interesting. Indeed, like the levels of reported online sales activity shown earlier, the revenues, assets, and employment in this group seem remarkably stable over the three-year period. Revenues in those reporting online sales activity remained basically level, and assets at the companies were falling. Their employment started higher than at companies without online activities and remained so over the period, but without growth. Only the falling level of assets at the companies reporting 
Table 12

Average Employment, Assets, Revenues over 2004-2009 Period by Use of Internet Activities

\begin{tabular}{|c|c|c|c|c|c|c|c|}
\hline & & \multicolumn{2}{|c|}{ Website } & \multicolumn{2}{|c|}{ Email } & \multicolumn{2}{|c|}{ Internet Sales* } \\
\hline & & Yes & No & Yes & No & Yes & No \\
\hline \multirow[t]{3}{*}{2004} & Employment & 2.3 & 1.6 & 1.9 & 1.4 & $\mathrm{~N} / \mathrm{A}$ & $\mathrm{N} / \mathrm{A}$ \\
\hline & Assets & $\$ 200,383$ & $\$ 124,787$ & $\$ 163,226$ & $\$ 107,436$ & $\mathrm{~N} / \mathrm{A}$ & $\mathrm{N} / \mathrm{A}$ \\
\hline & Revenues & $\$ 225,553$ & $\$ 168,098$ & $\$ 200,810$ & $\$ 135,088$ & $\mathrm{~N} / \mathrm{A}$ & $\mathrm{N} / \mathrm{A}$ \\
\hline \multirow[t]{4}{*}{2005} & Employment & 3.7 & 2.5 & 3.1 & 2.6 & $\mathrm{~N} / \mathrm{A}$ & $\mathrm{N} / \mathrm{A}$ \\
\hline & Assets & $\$ 230,935$ & $\$ 165,563$ & $\$ 192,595$ & $\$ 188,667$ & $\mathrm{~N} / \mathrm{A}$ & $\mathrm{N} / \mathrm{A}$ \\
\hline & Revenues & $\$ 459,967$ & $\$ 302,612$ & $\$ 387,758$ & $\$ 271,236$ & $\mathrm{~N} / \mathrm{A}$ & $\mathrm{N} / \mathrm{A}$ \\
\hline & Survived through 2005 & $95.0 \%$ & $90.4 \%$ & $92.7 \%$ & $89.6 \%$ & $\mathrm{~N} / \mathrm{A}$ & $\mathrm{N} / \mathrm{A}$ \\
\hline \multirow[t]{4}{*}{2006} & Employment & 4.4 & 2.9 & 3.6 & 2.7 & $\mathrm{~N} / \mathrm{A}$ & $\mathrm{N} / \mathrm{A}$ \\
\hline & Assets & $\$ 276,707$ & $\$ 210,943$ & $\$ 241,548$ & $\$ 212,337$ & $\mathrm{~N} / \mathrm{A}$ & $\mathrm{N} / \mathrm{A}$ \\
\hline & Revenues & $\$ 586,646$ & $\$ 401,250$ & $\$ 507,140$ & $\$ 329,362$ & $\mathrm{~N} / \mathrm{A}$ & $\mathrm{N} / \mathrm{A}$ \\
\hline & Survived through 2006 & $85.2 \%$ & $77.4 \%$ & $81.5 \%$ & $74.3 \%$ & $\mathrm{~N} / \mathrm{A}$ & $\mathrm{N} / \mathrm{A}$ \\
\hline \multirow[t]{4}{*}{2007} & Employment & 4.3 & 3.1 & 3.7 & 2.8 & 4.0 & 3.4 \\
\hline & Assets & $\$ 306,232$ & $\$ 188,546$ & $\$ 228,782$ & $\$ 280,469$ & $\$ 343,127$ & $\$ 363,052$ \\
\hline & Revenues & $\$ 691,910$ & $\$ 469,680$ & $\$ 594,229$ & $\$ 413,283$ & $\$ 550,847$ & $\$ 594,288$ \\
\hline & Survived through 2007 & $71.9 \%$ & $65.0 \%$ & $68.4 \%$ & $64.3 \%$ & $\mathrm{~N} / \mathrm{A}$ & $\mathrm{N} / \mathrm{A}$ \\
\hline \multirow[t]{4}{*}{2008} & Employment & 4.5 & 3.0 & 3.6 & 3.8 & 3.9 & 3.5 \\
\hline & Assets & $\$ 238,647$ & $\$ 212,685$ & $\$ 223,879$ & $\$ 218,710$ & $\$ 322,117$ & $\$ 365,755$ \\
\hline & Revenues & $\$ 664,206$ & $\$ 518,043$ & $\$ 615,494$ & $\$ 355,830$ & $\$ 537,516$ & $\$ 611,233$ \\
\hline & Survived through 2008 & $63.9 \%$ & $58.8 \%$ & $61.6 \%$ & $56.5 \%$ & $\mathrm{~N} / \mathrm{A}$ & $\mathrm{N} / \mathrm{A}$ \\
\hline \multirow[t]{4}{*}{2009} & Employment & 4.7 & 2.9 & 3.6 & 4.2 & 3.9 & 3.6 \\
\hline & Assets & $\$ 244,602$ & $\$ 192,269$ & $\$ 201,677$ & $\$ 286,904$ & $\$ 265,327$ & $\$ 365,919$ \\
\hline & Revenues & $\$ 729,669$ & $\$ 446,402$ & $\$ 582,277$ & $\$ 503,410$ & $\$ 563,991$ & $\$ 577,449$ \\
\hline & Survived through 2009 & $58.8 \%$ & $55.4 \%$ & $57.1 \%$ & $54.7 \%$ & $\mathrm{~N} / \mathrm{A}$ & $\mathrm{N} / \mathrm{A}$ \\
\hline
\end{tabular}

*Firms that had Internet sales in any of the years 2007-2009 and only those that survived until at least 2007. Website and email from 2004.

Source: Kauffman Firm Survey microdata.

online sales seems of particular trend and possible long-term impact.

We also examined measures of growth expectations and optimism among the different samples in the KFS. In most cases, it's interesting how similar the groups are in how their expectations for business growth were met, their future growth expectations, and their overall optimistic outlook.
As shown in Table 13, firms that had a website at founding had significantly higher growth expectations in their final years as a part of the KFS panel. Among those that started with a website, 27.6 percent expected 30-plus percent growth, compared with only 15.5 percent of the group that didn't start with a website. A similar differential forecast was seen in those firms that started with 
Figure 8

Assets and Revenues by Use of Website

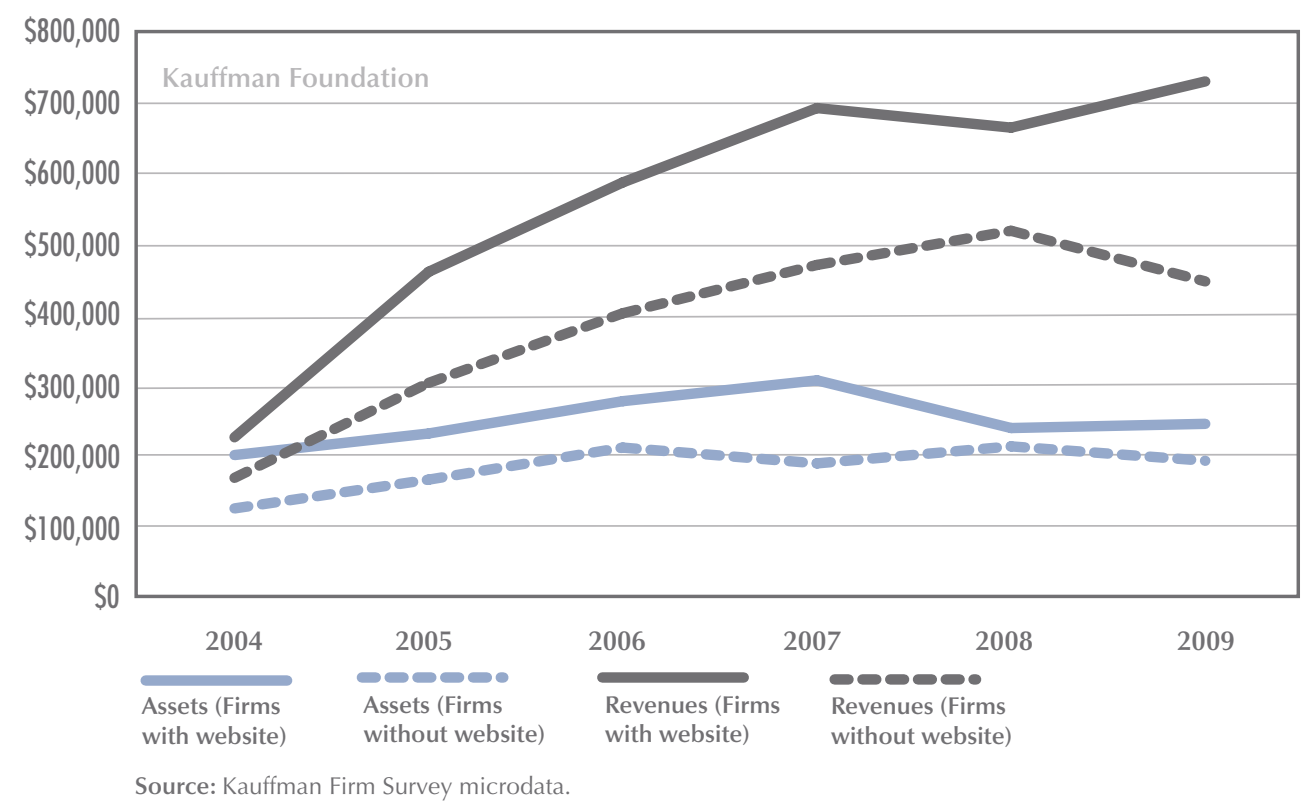

an email and those that did not (22.1 percent compared with 12.8 percent). These differences are interesting since the "optimistic outlook" tool included in the questionnaire shows very comparable levels of optimism in all categories examined here.

Table 13

Growth Expectations by Use of Internet Activities*

\begin{tabular}{|l|c|c|c|c|c|c|}
\cline { 2 - 7 } \multicolumn{1}{c|}{} & \multicolumn{2}{c|}{ Website } & \multicolumn{2}{c|}{ Email } & \multicolumn{2}{c|}{ Internet Sales** } \\
\cline { 2 - 7 } \multicolumn{1}{c|}{} & Yes & No & Yes & No & \multicolumn{2}{c|}{ Yes } \\
\hline $\begin{array}{l}\text { Met/Exceeded Growth } \\
\text { Expectations for 2004-2008 }\end{array}$ & $45.6 \%$ & $47.1 \%$ & $46.2 \%$ & $51.2 \%$ & $43.5 \%$ & $47.8 \%$ \\
\hline $\begin{array}{l}\text { High-Growth Expectations } \\
\text { for 2008-2011 (30+\%) }\end{array}$ & $27.6 \%$ & $15.5 \%$ & $22.1 \%$ & $12.8 \%$ & $25.2 \%$ & $20.1 \%$ \\
\hline "Optimistic Outlook" & $32.6 \%$ & $34.7 \%$ & $33.7 \%$ & $31.5 \%$ & $34.0 \%$ & $33.3 \%$ \\
\hline $\mathrm{n}$ & 1,340 & 1,069 & 2,341 & 68 & 934 & 1,790 \\
\hline
\end{tabular}

* Only firms that survived until at least 2008 .

**Firms that had Internet sales in any of the years 2007-2009 and only those that survived until at least 2007. Website and email from 2004. Source: Kauffman Firm Survey microdata. 
Table 14

Likelihood of Having Internet Sales (2007-2009)

\begin{tabular}{|l|c|c|}
\cline { 2 - 3 } \multicolumn{1}{c|}{} & $\begin{array}{c}\text { Any Internet Sales } \\
\text { in 2007-2009 }\end{array}$ & $\begin{array}{c}\text { Standard } \\
\text { Error }\end{array}$ \\
\hline Black & -0.00953 & $(0.223)$ \\
\hline Asian & 0.299 & $(0.283)$ \\
\hline Hispanic & 0.0239 & $(0.264)$ \\
\hline Female & 0.0227 & $(0.127)$ \\
\hline Team Ownership & 0.0588 & $(0.123)$ \\
\hline Owner Age & -0.00704 & $(0.00551)$ \\
\hline High-Growth Expectations & 0.185 & $(0.139)$ \\
\hline College Degree+ & 0.153 & $(0.125)$ \\
\hline Previous Startup Exp. & $0.428^{* * *}$ & $(0.116)$ \\
\hline Hours Worked (week) & $0.0112^{* * *}$ & $(0.00251)$ \\
\hline Wealth 250K+ & 0.138 & $(0.126)$ \\
\hline Firm Email & $0.652^{* * *}$ & $(0.200)$ \\
\hline Home-based & $0.210^{*}$ & $(0.126)$ \\
\hline Total Startup Capital & $-1.48 \mathrm{e}-08$ & $(1.42 \mathrm{e}-07)$ \\
\hline Urban & $0.330^{* *}$ & $(0.155)$ \\
\hline High Credit Score & $-0.308^{*}$ & $(0.180)$ \\
\hline Employer Firm & -0.00611 & $(0.120)$ \\
\hline Construction & $-0.631^{* *}$ & $(0.284)$ \\
\hline Manufacturing & $0.868^{* * *}$ & $(0.256)$ \\
\hline Wholesale Trade & $1.047^{* * *}$ & $(0.295)$ \\
\hline Retail Trade & $0.794^{* * *}$ & $(0.222)$ \\
\hline Transportation/Warehousing & 0.329 & $(0.397)$ \\
\hline Finance, Insurance, and Real Estate & 0.0101 & $(0.225)$ \\
\hline Professional, Management, & -0.118 & $(0.203)$ \\
\hline Admin. \& Support, Waste, & -0.238 & $(0.244)$ \\
\hline Remed. Services, Health Care, & & $\left(0.399^{* *}\right.$ \\
\hline Arts, Entertainment, Rec. & $-2.328^{* * *}$ & $(0.376)$ \\
\hline Constant & & \\
\hline
\end{tabular}

$\mathrm{n}=2159 ;{ }^{* * *} \mathrm{p}<0.01,{ }^{* *} \mathrm{p}<0.05, * \mathrm{p}<0.1$

Finally, we looked at what factors influenced the likelihood that a firm offered its products or services for sale through the Internet. As shown in Table 14, owners that had previous startup experience and who worked longer hours were more likely to have Internet sales. In terms of firm characteristics, firms that started with an email account, were home-based, located in an urban setting, or were in Manufacturing, Retail, and Arts, Entertainment, and Recreation were all significantly more likely to have Internet sales. Interestingly, firms with high credit-worthiness were significantly less likely to have Internet sales, as were Construction firms, controlling for other factors. 


\section{Conclusion}

Like most general-use technologies, the Internet is having a wide range of effects on business activity in the United States. We studied the influence of a business website, of an email address for the business owner, and of online sales in a panel dataset, examining firms started in 2004 (with data on them annually through 2009), and also examining incidence of a website and online sales in the general population of U.S. firms in 2007. Through this analysis, we see evidence that new businesses are entering differently from established businesses, bringing with them higher propensities for use of websites, email, and online sales. These new businesses start with higher propensities for using these technologies and increase their adoption rates through 2009 .

In general, startups that had websites were founded by entrepreneurs that tended to be more educated, were more likely to have startup experience, and were putting into the business about eight hours more in a given week than were startup founders who did not have websites. Startups without websites tended to have slightly older entrepreneurs with more industry work experience.

High-tech startups appeared most likely to have websites at launch and also to be using a business email at launch, but showed few differences in Internet sales trends. Across the measures examined in startups and established businesses, most of the industry-level trends appeared similar, with Manufacturing, Wholesale Trade, Professional Services, Retail Trade, FIRE, and Arts, Entertainment, and Recreation tending to have higher proclivities for websites and email, but with Professional Services and FIRE having lower levels of Internet sales.

We also examined how online sales typically play into a sales portfolio for a business. While a significant portion of businesses with online sales report more than half of their revenues from online sales (about 14 percent for all employer firms selling online), for most businesses online sales are part of an overall revenue stream. Young firms appear to be using online sales at higher rates and with greater likelihood that more than 50 percent of their sales will be generated online (about 26 percent of all online sellers).

Firms starting with websites tended to use more financial capital (almost \$55,000), and also were more likely to draw that capital from an outside equity source. Use of business email and Internet sales were associated with higher levels of initial financial capitalization, but did not seem to affect the mix of capital sources.

In examining outcomes, having a website was associated with the most differential performance. Firms that began with websites tended to start bigger (0.7 employees, $\$ 75,000$ in assets, and $\$ 57,000$ in revenues) and, by 2009 , had increased this differential significantly except in total assets (1.8 employees, $\$ 283,000$ in revenues). These firms also enjoyed a 3.4 percent better chance of survival through 2009.

In the future, we hope to examine further the impacts of online activities using the Kauffman Firm Survey. As a first step in this direction, we will publish the data on incidence of firm emails and websites used in this paper in the KFS data files. ${ }^{10}$ Additionally, we have posted on the KFS website a call for proposals to help us explore further research value that could be produced through an analysis of website content and/or other data augmentation procedures using the KFS sample. As we have shown in this paper, it appears that young firms are at the forefront in adopting certain new online activities, and we hope to expand research in this area in the near future. 


\section{References}

Bartelsman, Eric, John Haltiwanger, and Stefano Scarpetta, 2006.

"Reallocation and Productivity Growth: The FAQs,"

2006 Meeting Papers 293, Society for Economic Dynamics.

http://ideas.repec.org/p/red/sed006/293.html.

Brynjolfsson, Erik, and Michael D. Smith (2000). "Frictionless Commerce? A Comparison of Internet and Conventional Retailers," Management Science (46) No. 4, 563-585.

Charles, S. M., and A. Leduc Ivis, (2002). "Embracing E-Business: Does Size Matter?," research report, Statistics Canada.

Chapple, Karen, Ann Markusen, Greg Schrock, and Daisaku Yamamoto (2004). Gauging Metropolitan "High-tech" and "I-tech activity." Economic Development Quarterly 18 (1), 10-29.

Dinlersoz, Emin M., and Pedro Pereira (2007). "On the Diffusion of Electronic Commerce," International Journal of Industrial Organization (25) 541-574.

Forman, Chris, Avi Goldfarb, and Shane Greenstein (2003). "Which Industries Use the Internet?," Organizing the new industrial economy, Advances in Applied Microeconomics (12) 47-72.

Hadlock, Paul, Daniel Hecker, and Joseph Gannon. "High Technology Employment: Another View." Monthly Labor Review, July 1991, 26-30.

Hills, Gerald E., and Claes Hultman. "Small Business Poll: Promotion and Advertising." Volume 6, Issue 7, 2006. ISSN 1534-8326. Denny Dennis, series editor. http://www.411sbfacts.com/sbpoll. php?POLLID=0053.

Industry Canada (2010). Key Small Business Statistics. http://www.ic.gc. ca/eic/site/sbrp-rppe.nsf/vwapj/KSBS-PSRPE_July-Juillet2010_eng. pdf/\$FILE/KSBS-PSRPE_July-Juillet2010_eng.pdf.

Robb, Alicia M., Janice Ballou, David DesRoches, Frank Potter, Zhanyun Zhao, and E.J. Reedy. "An Overview of the Kauffman Firm Survey: Results from the 2004-2007 Data." Ewing Marion Kauffman Foundation, Kansas City, Mo., April 2009.

U.S. Census Bureau (2009). 2009 "E-Stats" Report. http://www.census.gov/econ/estats/2009/2009reportfinal.pdf. 


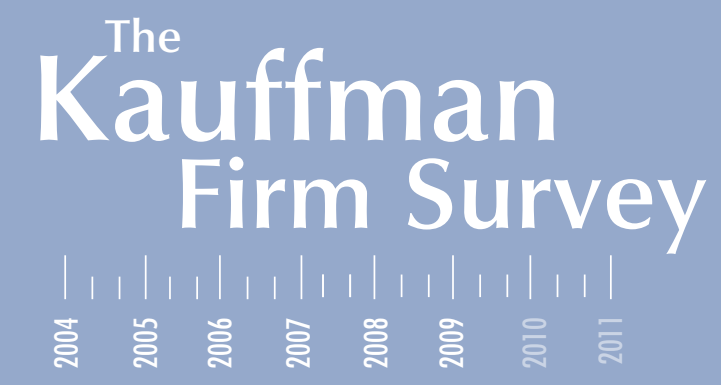




\section{KAUFFMAN}

The Foundation of Entrepreneurship

4801 ROCKHILL ROAD

KANSAS CITY, MISSOURI 64110

816-932-1000

www.kauffman.org 